Article

\title{
Urban Site Development as Temporal Carbon Storage-A Case Study in Germany
}

\author{
Annette Hafner * ${ }^{\mathbb{D}}$, Simon Slabik and Michael Storck \\ Resource Efficient Building, Ruhr-University Bochum, 44801 Bochum, Germany; \\ simon.slabik@ruhr-uni-bochum.de (S.S.); michael.storck@rub.de (M.S.) \\ * Correspondence: annette.hafner@rub.de; Tel.: +49-234-322-1413; Fax: +49-234-321-4815
}

Received: 25 June 2020; Accepted: 17 July 2020; Published: 20 July 2020

check for updates

\begin{abstract}
Increasing the use of sustainably sourced wood in construction for temporal carbon storage could be one vital part in the transition towards reaching the sustainable development goals for climate action and sustainable cities and communities. This paper explains the detailed steps from the planning to the realization process and shows how building with wood could be linked to the entire process from the sales of building plots to the realization of projects. Additionally, based on EN 15978, life cycle assessment (LCA) results of the constructed buildings were conducted to calculate the realistic carbon storage and the global warming potential for all new erected buildings on the site. The case study area and living lab is a building site in Munich with 566 flats, which will be finished in 2020 and will be the largest urban timber neighborhood in Germany by then. All development activities are summarized under the concept of building an eco-city with low carbon emissions and a high standard for living for all groups of inhabitants. Eight buildings with different material selections ranging from wood-constructions to wood-concrete hybrid constructions and concrete constructions with different energy standards are environmentally assessed. Results show that about 12.5 million $\mathrm{kg}$ of $\mathrm{CO}_{2}$ are stored in the wooden structures over the estimated life cycle of 50 years within this neighborhood. This clearly demonstrates the potential that building with wood has for achieving climate targets. Further results show that heating energy demand and material choices have a significant influence on LCA results.
\end{abstract}

Keywords: timber building; life cycle assessment; carbon storage; greenhouse gas reduction; sustainable neighborhoods; sustainable site development

\section{Introduction}

\subsection{General}

Following the Paris agreements and climate change discussions, strong action has to be taken in all sectors to achieve greenhouse gas (GHG) reductions. For staying within these budgetary frames, GHG emissions need to be mitigated and GHG removals increased. The building sector is accountable for about $40 \%$ of energy and process-related emissions [1] and thus has an important role in lowering GHG emissions, which corresponds exactly to sustainable development goal (SDG) 13: climate action. National and detailed local urban strategies have to specifically respond to the urbanization challenges of today, as laid out in SDG 11: sustainable cities and communities. This means a combination of approaches for both SDGs is requested by city authorities, which have to integrate environmental aspects amongst other aspects into city planning. Therefore, innovative possibilities are being investigated to integrate methods of GHG reduction into urban planning and thus create a climate-relevant effect. The currently emerging and partly still uncertain orientations and integration possibilities of climate targets on the urban and municipal levels will influence planning decisions 
for the coming decades. Worldwide efforts are currently being made to implement some of these requirements accordingly in the planning and conceptual design of new urban structures.

A review of the scientific literature shows that various international case studies have already been conducted concerning this issue. Calderon and Keirstead [2] reviewed energy and carbon models for the United Kingdom, distinguishing between accounting-style inventory tools and policy modeling tools. As a conclusion, the relevance of such models to assess greenhouse gas emissions was strongly emphasized for local authorities. Wang et al. [3] also advocate the need for local governments and policymakers to establish carbon management systems and policy evaluation accordingly for the transition to a low-carbon model in China. They suggest that a low-carbon development can only be achieved structurally in urban planning if objective-oriented indicators are utilized for realization. A case study from New Zealand illustrates the potential for increased timber construction in an urban context. Stocchero et al. [4] found that the goal of reducing greenhouse gas emissions in Auckland until 2040 by $40 \%$ can be achieved $20 \%$ faster by maximizing the timber construction quota. At the same time, the growing demand for housing can be met. Also, attention is given to the potential greenhouse gas savings that low-carbon footprint materials offer.

Harris et al. [5] brought together the sustainability strategies of ten different European cities in a further paper. A business as usual scenario was compared with a future-oriented sustainable scenario (post-carbon). The latter was elaborated on by stakeholders of the respective cities. Semi-quantitative indicator analysis, greenhouse gas emissions balancing, land requirements and cost-benefit analyses showed clear advantages for the post-carbon sustainable and future-oriented scenario. However, it was found that none of the cities studied will achieve the objectives of the Paris Climate Change Agreements of 2016 with the strategies adopted so far. The need for carbon reduction and storage became evident once again.

Nygaard et al. [6] investigated the environmental effects of increasing the rate of timber buildings in Oslo and Akershus, Norway. Three scenarios for the future use of timber in construction projects were investigated: (i) current use, (ii) a moderate increase and (iii) the theoretical maximum possible increase. When considering the increasing demand for housing, energy and material substitution as well as carbon storage resulted in a reduction in carbon emissions of $6.0 \%$ respectively $12.1 \%$ of the accumulated reduction targets between 2015 and 2030. A preliminary examination of different sustainability options and their potential may significantly simplify the planning process and the actual implementation of urban development concepts.

\subsection{Urban Site Developments}

Urban areas are responsible for over $70 \%$ of carbon dioxide emissions [7]. The pathway towards carbon neutrality thus goes along with the urban transition processes. In addition to the resilient adaptation of cities, a significant reduction in greenhouse gas emissions is essential. Within a complex network, such as a city, only superordinate authorities are capable of planning and applying sensible and orderly measures for sustainable development. Hence, it is the task of urban authorities in urban planning to define the standards for eco-efficiency of cities and buildings for the next centuries. Building permits authorize them to ensure the environmental and social quality of cities and buildings (SDG 11). By applying given control mechanisms, the objectives pursued by the authorities can be implemented more effectively and more extensively.

As the relevance of city authorities will increase regarding a comprehensive integration of resource and energy efficiency as well as low carbon buildings, appropriate tools are necessary. Therefore, instructions and tools enabling the reduction of greenhouse gas emissions of a neighborhood during the use phase need to be established. 
A framework is needed to ensure the full potential of carbon storage measures for building. This paper does not only refer to the possibilities for temporary carbon storage, but also aims to point out stakeholder activation, which is fundamental to urban site development. In addition, a tendering process is examined in which specifications for material and energy performance of the buildings are incorporated. The combination of involvement of city authorities and a tendering process aiming at sustainability is crucial to the urban contribution to climate protection. Considering the path taken, further projects can be accomplished.

\subsection{Temporary Carbon Storage}

As trees grow, they fix carbon from the atmosphere into their biomass. When these raw materials are processed into construction products, the stored carbon is brought to the building. This forms a temporary storage of biogenic carbon within the structure. After being used in the building, the bio-based materials maintain their carbon storage in possible next material use. Ultimately, as bio-based products decompose or are incinerated, carbon is released from the biomass.

Increasing the use of sustainably sourced wood in the construction as temporal carbon storage could be one vital part in the transition towards reaching GHG reduction targets when combined with other appropriate actions. Various studies from the recent years showed that timber buildings could be one component in climate actions as wood is a temporal carbon storage and additionally can substitute more energy intensive materials [8]. Potential GHG impacts of wood consumption in the building sector based on an insinuated future increase of the market share of timber buildings are modeled in [9]. The deviation of future emissions and removals due to the biogenic carbon storage effects for changing scenarios is presented. Additionally, the reduction potential of substituting energy intensive materials with lower emissions materials is quantified in Life Cycle Assessment (LCA) calculations and showing the substantial potential to lower GHG emissions by using timber buildings is described in [10].

\section{Method}

This paper aims to present new results from a case study and can show a way how to transfer these results to other site developments in Europe.

With a living lab approach, the paper describes the procedure applied to a new site development for residential housing. The aim of the living lab is to show how temporal carbon storage and building with wood could be included in site development and how much carbon storage can be expected as a result. The paper explains the detailed steps from the initial planning to the realization from the year 2014 to 2020. Additionally, the life cycle assessment (LCA) results, based on EN 15978, as well as the carbon storage are calculated for all new erected buildings on the site.

The living lab approach is illustrated as follows: Co-creation (i), Exploration (ii), Experimentation (iii) and Evaluation (iv) [11]. (i) and (ii) have been examined in the development of the concept and were described in detail in [12]. These parts are only summarized shortly in this paper. The main focus of this paper is on the implementation and evaluation of the environmental requirements and their transferability to other urban developments. Economic requirements are addressed in the living lab by using binding requirements defined in the initial concept and through the fact that the sites are sold by the relevant city via concept tendering. That means the best concept implementing all the required specifications will get the chance to buy the site, rather than the highest bidder.

A development in the city of Munich serves as the case study. The case study area is a building site in the north of Munich with 566 flats, which will be finished in 2020 and will be the largest urban timber neighborhood in Germany by then. 


\subsection{Co-Creation}

Developing a new neighborhood in Munich, as illustrated in Figure 1, the city administration wanted to showcase what the concept of an eco-city could mean. On the one hand, the objective was also to promote urgently needed social housing and, on the other hand, to consider issues such as energy efficiency and environmental impacts, as well as innovative approaches in terms of practical realization.

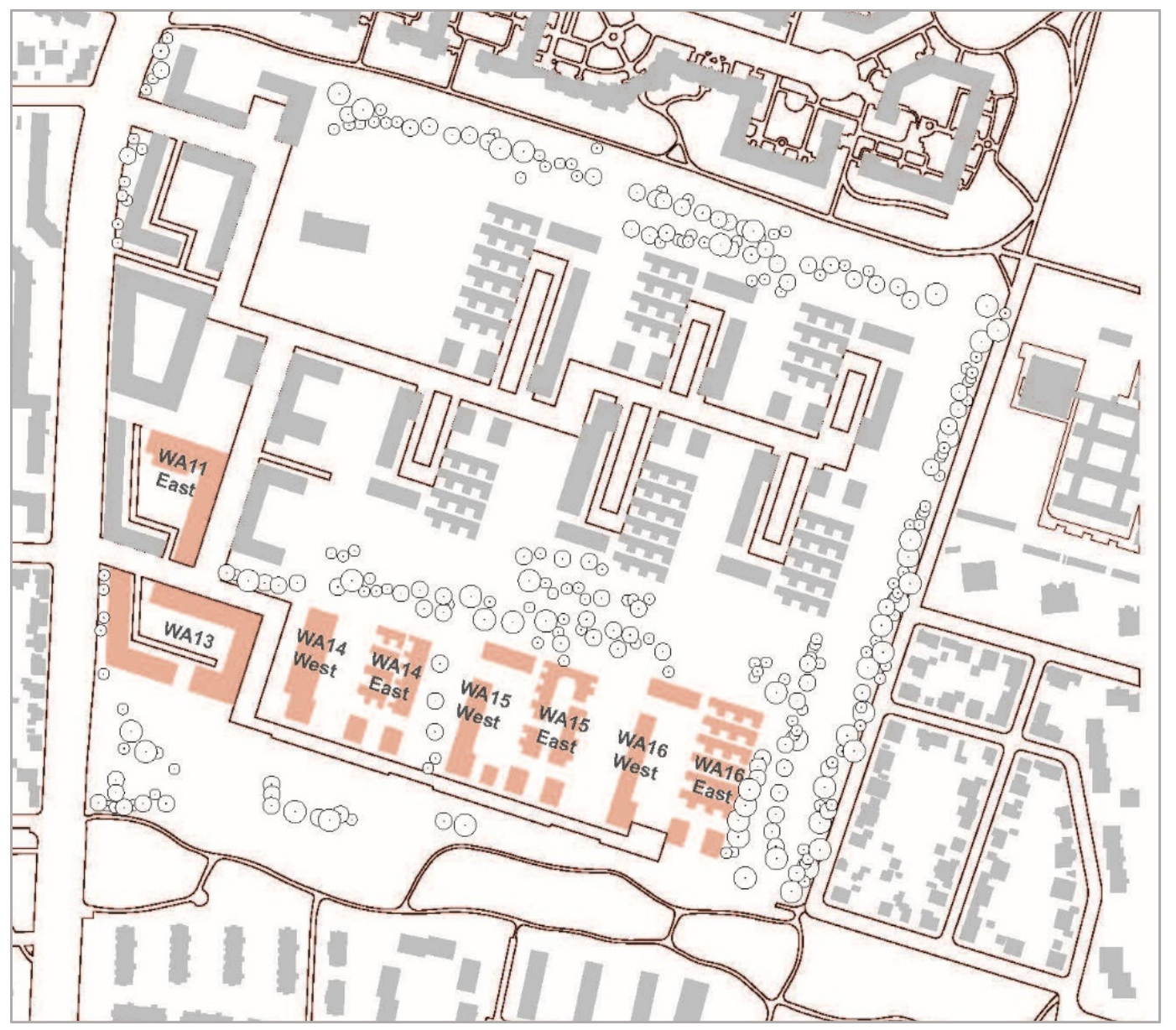

Figure 1. Masterplan for the site in Munich. Light red buildings belong to the described neighborhood.

Therefore, they set up requirements such as reducing carbon emissions, reaching a high standard in energy saving regulations, connecting the neighborhood to district heating with a high share of renewable energy and using renewable building materials. The neighborhood is characterized by good connections to public transport and the possibilities of utilization of the buildings for special target groups as well as the reservation of certain buildings for social housing. Besides the mentioned features, the case study contains a deeper focus on additional eco-city targets. Further requirements and goals are described in [12].

\subsection{Exploration}

To achieve these requirements, the city authorities created a tendering process which is detached from the highest price for the building site. The tendering process for the buildings was organized through a competition of concepts. A clearly defined evaluation system and special requirements for carbon storage were applied, which had previously been made available to the public. Thus, the promised concepts were stipulated in the legal buying agreement, and a penalty was to be imposed in the event of non-compliance with the criteria. In addition, subsidies to support the planning and 
building with renewable material on an economic basis were established. The buyers committed to discuss their proposals with a panel of experts several times during the planning process. The bidder should thus be supported in integrating their intended renewable raw materials into the planning. Furthermore, an early integrated planning approach regarding the structural framework and the fire safety regulations in connection to building with wood should be made possible. Additionally, as the case study is the first building site with these requirements, an additional grant was given based on the amount of stored carbon in the buildings. The combination of selling the buildings and the agreement to build primarily with wood as well as other requirements formed the focus. A description of the tendering of the site, especially the connection between the sales of building plots connected with the use of wood, is explained in [12].

\subsection{Experimentation}

As a result of this tendering process, eight different buildings were planned and erected on the site. Within these, there are many shared areas such as community gardens, kindergartens, small shopping facilities, workshops etc. Material choices of the buildings widely range from massive timber constructions over wood-concrete to concrete constructions. The decisive material use in the building sections are described in Table 1. Building sites such as WA 14 East use massive timber constructions in the entire building even for elevator shafts, whereas WA 13 mostly uses concrete structures with a timber frame exterior wall. This demonstrates the leeway of construction and within this, the possibility of using wood and wood-concrete hybrid constructions for residential buildings. All buildings use district heating and have a high energy standard. In order to fulfill fire protection requirements, a catalogue with possible construction details for large residential buildings in wood was developed by the Technical University of Munich [13].

\subsection{Evaluation}

The results of this paper are intended to demonstrate the whole process from tendering the building plots, which focused on low environmental footprint, up to realization of the single buildings. This paper acts as showcase for that. All the single buildings comply with different heating demands and are constructed in different ways. Therefore, results are expected to demonstrate the influence of material choices and energy standards on LCA evaluation. Further, the results demonstrate the expected potential carbon storage by determining the use of renewable materials such as wood as a building material in the tendering process of building sites.

\subsection{LCA-Method}

To demonstrate the environmental quality and environmental impacts of a building, Life Cycle Assessments are carried out. These are defined by the standardization of EN ISO 14040 [14] as "compilation and calculation of the inputs, outputs and the potential environmental impacts of a product system throughout its life cycle". The product system in this context is a building. Within these assessments, it is also possible to calculate the amount of carbon stored within the building.

Calculation rules of building LCAs are defined within the standard EN 15978 "Sustainability of buildings-Assessment of the environmental quality of buildings" [15] and EN 15804 "Sustainability of construction works-environmental product declarations" [16]. An important goal of building LCAs is to display the entire life cycle of the building beginning with the manufacturing of components and ending with the disposal of materials or even their further use in a following life cycle. 
Table 1. Constructive specifications of the selected sites.

\begin{tabular}{|c|c|c|c|c|c|c|c|c|}
\hline & WA 11 East & WA 13 & WA 14 West & WA 14 East & WA 15 West & WA 15 East & WA 16 West & WA 16 East \\
\hline \multicolumn{9}{|l|}{ Floor plan } \\
\hline GFA & $9115 \mathrm{~m}^{2}$ & $17,200 \mathrm{~m}^{2}$ & $6527 \mathrm{~m}^{2}$ & $4430 \mathrm{~m}^{2}$ & $7132 \mathrm{~m}^{2}$ & $5075 \mathrm{~m}^{2}$ & $9785 \mathrm{~m}^{2}$ & $5662 \mathrm{~m}^{2}$ \\
\hline Floors & 5 & 5 & $4-6$ & $2-4$ & $3-7$ & $2-4$ & $3-7$ & $2-4$ \\
\hline Flats & 82 & 181 & 57 & 36 & 45 & 39 & 87 & 39 \\
\hline $\begin{array}{l}\text { Averaged heating } \\
\text { demand }\end{array}$ & $56.30 \mathrm{kWh} / \mathrm{m}^{2} \mathrm{a}$ & $69.30 \mathrm{kWh} / \mathrm{m}^{2} \mathrm{a}$ & $78.98 \mathrm{kWh} / \mathrm{m}^{2} \mathrm{a}$ & $39.12 \mathrm{kWh} / \mathrm{m}^{2} \mathrm{a}$ & $48.35 \mathrm{kWh} / \mathrm{m}^{2} \mathrm{a}$ & $57.60 \mathrm{kWh} / \mathrm{m}^{2} \mathrm{a}$ & $66.14 \mathrm{kWh} / \mathrm{m}^{2} \mathrm{a}$ & $52.62 \mathrm{kWh} / \mathrm{m}^{2} \mathrm{a}$ \\
\hline $\begin{array}{c}\text { Decisive } \\
\text { structure of the } \\
\text { exterior wall }\end{array}$ & timber-frame & timber-frame & timber-frame & timber-frame & massive timber & timber-frame & massive timber & timber-frame \\
\hline $\begin{array}{l}\text { Additional } \\
\text { information } \\
\text { about the } \\
\text { exterior wall }\end{array}$ & - & - & $\begin{array}{c}\text { timber-frame } \\
\text { (4 story buildings) } \\
\text { timber-frame } \\
\text { (6 story building) }\end{array}$ & - & $\begin{array}{l}\text { concrete ground } \\
\text { floor of the } 5 \text { and } \\
7 \text { story buildings }\end{array}$ & $\begin{array}{l}\text { wood-concrete } \\
\text { (hybrid) walls in } \\
\text { the staircases }\end{array}$ & $\begin{array}{c}\text { timber-frame, } \\
\text { massive timber } \\
\text { ( } 3 \text { story building) } \\
\text { concrete ( } 5 \text { and } \\
7 \text { story buildings) }\end{array}$ & $\begin{array}{c}\text { timber-frame } \\
\text { (4 story house) } \\
\text { timber-frame, } \\
\text { massive timber } \\
\text { (2-3 story buildings) }\end{array}$ \\
\hline Interior wall & $\begin{array}{l}\text { massive timber, } \\
\text { concrete }\end{array}$ & concrete & $\begin{array}{l}\text { massive timber, } \\
\text { concrete }\end{array}$ & massive timber & $\begin{array}{l}\text { massive timber, } \\
\text { concrete }\end{array}$ & $\begin{array}{l}\text { massive timber, } \\
\text { timber-frame }\end{array}$ & $\begin{array}{l}\text { massive timber, } \\
\text { concrete }\end{array}$ & $\begin{array}{l}\text { timber-frame, } \\
\text { concrete }\end{array}$ \\
\hline Roof & massive timber & concrete & wood-concrete & massive timber & massive timber & massive timber & massive timber & massive timber \\
\hline Floor ceiling & massive timber & concrete & wood-concrete & massive timber & massive timber & $\begin{array}{l}\text { massive timber, } \\
\text { concrete (GF) }\end{array}$ & $\begin{array}{l}\text { massive timber, } \\
\text { concrete }\end{array}$ & $\begin{array}{l}\text { massive timber, } \\
\text { concrete (GF) }\end{array}$ \\
\hline $\begin{array}{l}\text { Staircase \& } \\
\text { lift shaft }\end{array}$ & concrete & concrete & concrete & massive timber & concrete & concrete & concrete & concrete \\
\hline Special features & $\begin{array}{l}\text { ground floor of } \\
\text { the north wing } \\
\text { made of } \\
\text { concrete, retail } \\
\text { on the ground }\end{array}$ & $\begin{array}{l}\text { skeleton } \\
\text { construction } \\
\text { with concrete } \\
\text { columns }\end{array}$ & $\begin{array}{l}\text { wood-concrete } \\
\text { (hybrid) } \\
\text { construction of } \\
\text { the floor ceiling } \\
\text { and the roof }\end{array}$ & $\begin{array}{l}\text { massive timber } \\
\text { construction in } \\
\text { the entire } \\
\text { building }\end{array}$ & - & $\begin{array}{l}\text { Access to the } \\
\text { apartments } \\
\text { through } \\
\text { a pergola }\end{array}$ & $\begin{array}{l}\text { Access to the } \\
\text { apartments of the } 5 \\
\text { and } 7 \text { stories building } \\
\text { through a pergola }\end{array}$ & - \\
\hline
\end{tabular}

Note: All basements are made of reinforced concrete. 
The life cycle of a building in LCA calculations is divided into different life cycle stages, which are defined in the standardization of EN 15978 [15]. The main life cycle stages are the manufacturing and construction phase (module A), the use stage (module B) and the disposal phase (module C). These life cycle phases are further subdivided into smaller units.

In this paper, the LCA calculation rules follow the Guideline for Sustainable Building developed by the German Federal Ministry of the Interior, Building and Community [17]. All calculations were made using the LCA-software LEGEP. The cut-off criteria are determined as in EN 15804 [16]. The functional unit is one square meter of the gross floor area $\left(\mathrm{m}^{2} \mathrm{GFA}\right)$. As a background database, the German oekobaudat was used. Therefore, results are limited to a German context. The heating energy demand of the buildings during the use stage (module B6) were also analyzed by their global warming potential, as well as their primary energy consumption. Recent studies indicate that the heating energy demand has a major influence on the overall results [18].

In the first step, all building materials of the buildings had to be compilated and exchange rates for these were assigned, the replacement cycles are determined by [19]. The heating energy for the analyzed neighborhood is provided through district heating and within this, the share of renewable primary energy was set to $89 \%$. To ensure a better comparison of the results, no underground parking areas were counted. In three of the eight building sites, parts of the ground floor were non-residential with two kindergartens and small shops. As these are relatively small in comparison to the living space, they were also calculated as part of the living space.

To calculate the temporary carbon storage of the buildings, calculation rules within the standardization of EN 16485:2014 "Round and sawn timber-Environmental Product Declarations" [20] were used. The amount of carbon stored depends on the mass of renewable materials used within the structure. In the life cycle stages, the stored carbon is counted as a negative value within the global warming potential results for the construction phase. At the disposal phase, the stored carbon is released and counted as being positive with the same value as in module A. The buildings are therefore considered to be climate neutral.

\section{Results}

\subsection{Site Development}

The tendering process shows that the sale of sites to the bidder with the best specifications for eco-efficiency works and is feasible. For all sites, there were multiple bids and the best concept could be chosen. The approach requires clear political will in the early planning stage, but as in these sites, this general process can be viewed as a role model for broader climate change mitigation actions. The approach can be transferred to other building sites and with slightly adapted specifications to other cities and communities.

The will to create and communicate advantages of this approach is also important. For an exact description of the procedure, see [12].

\subsection{Stored Carbon and Global Warming Potential Results}

Below, the absolute carbon storage for the different sites is shown in Figure 2. Overall, the amount of $\mathrm{CO}_{2}$ stored is highly influenced by the decisive components used, such as massive timber, timber-frame or concrete components. As it can be seen in Figure 2, the site with the largest absolute carbon storage of $1,935,312 \mathrm{~kg} \mathrm{CO}$-eq. is WA 16 East, which is mainly being constructed using massive timber. In contrast, the sites with the lowest absolute carbon storage are WA 15 East which is a relatively small site with 39 flats, and WA 13, a large site predominantly built with concrete constructions containing 180 flats in total. Cumulated, the neighborhood has a temporary carbon storage capacity of $12,532,130 \mathrm{~kg} \mathrm{CO}_{2}$-eq. over the estimated lifecycle of 50 years for all renewable materials. 


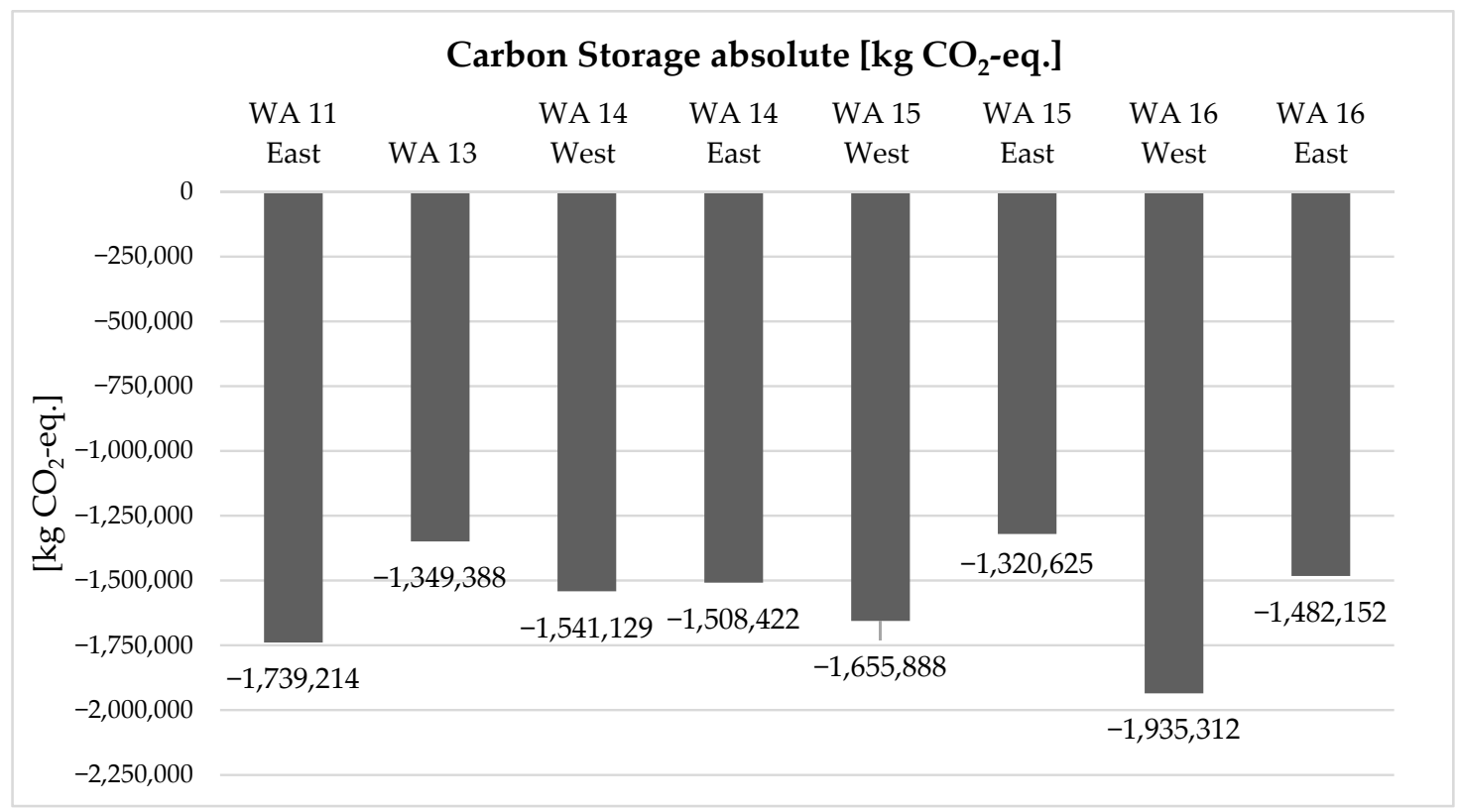

Figure 2. Absolute biogenic carbon stored by building site.

The difference in material choice becomes even more evident when the gross floor area is considered. Accordingly, the relative biogenic carbon stocks per $\mathrm{m}^{2}$ GFA are given in Table 2. Due to the high share of reinforced concrete, WA 13 has by far the lowest carbon storage. In contrast, WA 14 East, with predominantly massive timber and timber-frame walls and additional elevator shafts and staircases in massive timber, provides the highest relative biogenic carbon storage.

Table 2. Relative biogenic carbon stored by building site.

\begin{tabular}{cc}
\hline Carbon Storage Relative $\left[\mathbf{k g ~ C O}\right.$-eq. $\left./ \mathbf{m}^{2} \mathbf{G F A}\right]$ \\
\hline WA 11 East & -4.12 \\
WA 13 & -1.39 \\
WA 14 West & -4.98 \\
WA 14 East & -5.79 \\
WA 15 West & -4.31 \\
WA 15 East & -4.58 \\
WA 16 West & -5.10 \\
WA 16 East & -3.90 \\
\hline
\end{tabular}

Further, the cubature of the building, the ratio of building envelope to building volume and the number of floors are sensitive determinants for the potential carbon storage of a building. However, the structure of a building, which consists mainly of wood, is regulated in Germany by various state building regulations. In particular, the requirements for fire protection are restrictive specifications for the construction of buildings.

Figure 3 displays the global warming potential (GWP) results of the material over the lifecycle in $\mathrm{kg} \mathrm{CO}$-eq. The GWP is divided in GWP fossil and GWP biogenic materials to highlight used GWP and stored carbon in construction. The light grey columns show the stored carbon which is released in the end of life (module C). The negative value of module $\mathrm{A}$ is equal to the results side in Figure 2. It is to be seen that WA 13 has the highest value in module $A$ and $C$ and has a relatively low carbon storage capacity. This is mostly due to the use of reinforced concrete structures within the building and the large building size. The released carbon in module $C$ causes comparative high global warming potential results for wooden buildings in the end of life stage. In relation to the other modules, module B2-4 has only a small influence on the overall result. 




Figure 3. Global warming potential (GWP) results of materials through the life cycle, divided into fossil and biogenic materials.

In addition, Figure 4 shows the global warming potential results for the material use, as the sum of the modules A1-A3, B2-B4 and module $\mathrm{C}$ as well as the global warming potential for the heating energy demand (B6). As in this case, heating energy is provided through district heating with a high share of renewable primary energy $(89 \%)$ the influence of module B6 is relatively small in comparison to other LCA results [18]. The highest absolute GWP is evoked by WA 13 with 12,293,318 $\mathrm{kg} \mathrm{CO}_{2}$-eq., which is the largest building complex on the one hand and one of the buildings with comparatively poorer energy standards on the other. In contrast, the lowest value of 2,723,041 $\mathrm{kg} \mathrm{CO}$-eq. is produced by WA 15 East, where the buildings have significantly lower heating demands.



Figure 4. Global Warming Potential results; comparison of heating energy and influence of the materials. 
The share of heating energy demand emissions compared to material emissions range from about $31 \%$ (WA 14 West) to $19 \%$ for WA 16 West, which is comparable to high averaged heating demands, described in Table 1. The results again depend on various aspects including the size of the building, the material choice, the energetic standard, the cubature and other factors. By minimizing the heating energy emissions through optimizing energetic standards, the share of the material choice becomes larger. The results in this paper lead to the conclusion that reducing the heating energy demand and at the same time minimizing emissions of materials is a task for future sustainability in the construction sector.

\section{Discussion}

The paper described the entire process of selling building plots connected to the agreement to build with wood and displayed the resulting carbon storage as well as the LCA results of the constructed sites. A key factor in this tendering process was to sell the site to the bidder with the best concept and not to the one with the highest price. Future discussions should critically elaborate the conditions for creating an evaluation system of tendering processes. Environmental, economic as well as social aspects should hereby be weighted equally.

The entire tendering process and particularly the compliance with legal framework conditions require a high degree of motivation and willingness of urban planners and authorities to carry out sustainable urban projects. Standard constructions and simplified legal frameworks, especially for fire protection, could in future facilitate the construction of multi-story residential buildings with a high share of wooden construction materials.

The energy demand of a building is mainly composed by the heating energy demand of the building, as well as the energy demand of the materials. The reduction of heating energy demand must continue to be a priority in the construction of buildings in the future. Further energy reductions can be achieved using low-energy building materials such as wood. The complex relations between the energy supply and the choice of material are also referred to in [18]. Therefore, all building variants examined had the same cubature. The additional influence of the building cubature can nonetheless be deduced from the neighborhood investigated in this paper. It was found that the energy-intensive production of mineral building materials is particularly precarious. In contrast to this, the low thermal storage capacity of wooden building elements is a disadvantage. A stand-alone and optimal solution therefore seems not to exist. In any case, when improving the energy standard of a building, the influence of the material choice rises, meaning building with timber can therefore be advantageous. However, combined solutions can be beneficial.

The buildings considered in this paper differ in their cubature, building materials and energetic standards. In this regard, it is not possible to give precise information about the influence of these parameters. Therefore, future research will have to build on this. Nevertheless, results indicate that the combination of minimizing heating energy, using renewable materials and optimizing the cubature of buildings are important to lower environmental impacts.

In this case study, all buildings are supplied with 0.1 as a low primary energy factor. If this is raised, then the impact of the heating energy as well as the buildings cubature becomes larger. Besides, it is crucial to provide the remaining energy demand using renewable energy sources to achieve climate targets.

To gain a positive effect on climate targets, it is essential that the wood used is sourced from sustainable forestry. Short distances to the construction site also reduce emissions. Results from Germany show that sufficient wood from the relevant species and diameters is available to plan further timber building neighborhoods [21].

\section{Conclusions}

The building sector has been identified as a major contributor to achieving SDG 11 and SDG 13 in Europe. The described living lab approach is one way to achieve high carbon storage and to lower 
GHG emissions in the building sector by governing this through specifications and requirements for selling building plots. These requirements make use of already developed technologies (building with wood) and can easily be combined with other requirements (e.g., mobility, biodiversity). The key to this is the connection of fixed price rate for plots and best concept in regard to proposed (environmental) and other requirements.

In this case, a total of $12,532,130 \mathrm{~kg} \mathrm{CO}$-eq. is stored using timber as main structural building material for 566 flats over 50 years. As the realization is made in compliance with all technical standards (in Germany, 2019), there might even be a better performance if timber construction for urban residential buildings is simplified in the future.

Through the large-scale implementation of the presented concepts in the residential building sector, significant climate-relevant effects can be realized in a short-term manner. An increased timber construction quota offers high potential for carbon storage and, through the substitution of mineral building materials, a significant reduction potential for greenhouse gas emissions at a large scale is also possible, as shown for Germany in [22].

Author Contributions: Conceptualization, methodology, A.H.; software, formal analysis, investigation, data curation, M.S. and S.S.; writing—original draft preparation as well as writing—review and editing, A.H., M.S. and S.S.; visualization, M.S.; supervision and funding acquisition, A.H. All authors have read and agreed to the published version of the manuscript.

Funding: This study was carried out on basis of the research project "Resource efficient neighborhood developmentPrinz-Eugen-Park, Munich" funded by the DBU—German federal Environmental Foundation, AZ: 34301/01-25. The authors gratefully acknowledge the assistance of all concerned. We acknowledge support by the DFG Open Access Publication Funds of the Ruhr-Universität Bochum.

Conflicts of Interest: The authors declare no conflict of interest.

\section{References}

1. Global Alliance for Buildings and Construction, International Energy Agency and the United Nations Environment Programme (2019): Global Status Report for Buildings and Construction 2019: Towards a zero-emission, efficient and resilient buildings and construction sector. Available online: https://www.iea. org/reports/global-status-report-for-buildings-and-construction-2019 (accessed on 11 July 2020).

2. Calderon, C.; Keirstead, J. Modelling frameworks for delivering low-carbon cities: Advocating a normalized practice. Build. Res. Inf. 2012, 40, 504-517. [CrossRef]

3. Wang, Y.; Song, Q.; He, J.; Qi, Y. Developing low-carbon cities through pilots. Clim. Policy 2015, 15, 81-103. [CrossRef]

4. Stocchero, A.; Seadon, J.K.; Falshaw, R.; Edwards, M. Urban Equilibrium for sustainable cities and the contribution of timber buildings to balance urban carbon emissions: A New Zealand case study. J. Clean. Prod. 2017, 143, 1001-1010. [CrossRef]

5. Harris, S.; Weinzettel, J.; Levin, G. Implications of Low Carbon City Sustainability Strategies for 2050. Sustainability 2020, 12, 5417. [CrossRef]

6. Nygaard, M.; Bashevkin, I.E.S.; Groba, U.; Sunter, C. Increased Use of Timber in New Buildings in Oslo and Akershus: Potentials and GHG Emission Effects. Front. Built Environ. 2019, 5, 131. [CrossRef]

7. International Energy Agency (2016), Energy Technology Perspectives 2016, IEA, Paris. Available online: https://www.iea.org/reports/energy-technology-perspectives-2016 (accessed on 11 July 2020).

8. Rüter, S.; Werner, F.; Forsell, N.; Prins, C.; Vial, E.; Levet, A.-L. ClimWood2030, Climate benefits of material substitution by forest biomass and harvested wood products: Perspective 2030-Final Report. Thünen Rep. 2016, 42, 1-142. [CrossRef]

9. Hafner, A.; Rüter, S. Method for Assessing the National Implications from Timber Buildings-An Environmental Study for residential Buildings in Germany. J. Wood Fiber Sci 2018, 50, 139-154. [CrossRef]

10. Hafner, A.; Schäfer, S. Comparative LCA study of different timber and mineral buildings and calculation method for substitution factors on building level. J. Clean Prod. 2017, 167, 630-642. [CrossRef] 
11. Pallot, M. Engaging Users into Research and Innovation: The Living Lab Approach as a User-Centred Open Innovation Ecosystem. Webergence Blog. 2009. Available online: https://web.archive.org/web/20120509081658/ http://www.cwe-projects.eu/pub/bscw.cgi/1760838?id=715404_1760838 (accessed on 10 July 2020).

12. Hafner, A. How buildings with wood can be linked to sales of building plots: Results from an exemplary site development in Munich, Germany. Sustainability 2017, 9, 947. [CrossRef]

13. Gräfe, M.; Merk, M.; Werther, N.; Winter, S. Erarbeitung weiterführender Konstruktionsregeln/-Details für mehrgeschossige Gebäude in Holzbauweise der Gebäudeklasse 4. 2014. Available online: https://www. irbnet.de/daten/baufo/20138035839/140731_mg_mehrgeschossiger\%20Holzbau\%20Abschlussbericht.pdf (accessed on 10 July 2020).

14. DIN EN ISO 14040:2009-11_Environmental Management_Life Cycle Assessment_Principles and Framework (ISO 14040:2006); German and English Version EN ISO 14040; Beuth Verlag GmbH: Berlin, Germany, 2006. [CrossRef]

15. DIN EN 15978:2012-10-Sustainability of Construction Works-Assessment of Environmental Performance of Buildings_Calculation Method; German Version EN 15978:2011; Beuth Verlag GmbH: Berlin, Germany, 2011. [CrossRef]

16. DIN EN 15804:2014-07-Sustainability of Construction Works—Environmental Product Declarations-Core Rules for the Product Category of Construction Products; German Version EN 15804:2012+A1:2013; Beuth Verlag GmbH: Berlin, Germany, 2015. [CrossRef]

17. Federal Ministry of the Interior, Building and Community. Guideline for Sustainable Building. 2019. Available online: https://www.nachhaltigesbauen.de/fileadmin/pdf/Leitfaden_2019/BBSR_LFNB_E_komplett_KOR1_ 190503.pdf (accessed on 10 July 2020).

18. König, H. Lebenszyklusanalyse von Wohngebäuden-Lebenszyklusanalyse mit Berechnung der Ökobilanz und Lebenszykluskosten, Bavarian Environmental Agency. Available online: https:/legep.de/wp-content/ uploads/Endbericht-Lebenszyklusanalyse_von_Wohngebaeuden.pdf (accessed on 23 March 2020).

19. Federal Ministry of the Interior, Building and Community. Nutzungsdauern von Bauteilen zur Lebenszyklusanalyse nach BNB. 2017. Available online: https://www.nachhaltigesbauen.de/de/baustoffund-gebaeudedaten/nutzungsdauern-von-bauteilen.html (accessed on 10 July 2020).

20. DIN EN 16485:2014-07-Round and Sawn Timber-Environmental Product Declarations—Product Category Rules for Wood and Wood-Based Products for Use in Construction; German Version EN 16485:2014; Beuth Verlag GmbH: Berlin, Germany, 2014.

21. Scientific Advisory Board for Forest Policy (WBW) at the Federal Ministry of Food and Agriculture. Erhöhung der stofflichen Nutzung von Holz in Gebäuden im Einklang mit der Rohstoffverfügbarkeit. 2018. Available online: https://www.bmel.de/SharedDocs/Downloads/DE/_Ministerium/Beiraete/waldpolitik/ StellungnahmeWBW-stofflicheNutzungHolz.pdf?_blob=publicationFile\&v=3 (accessed on 10 July 2020).

22. Hafner, A.; Rüter, S.; Ebert, S.; Schäfer, S.; König, H.; Cristofaro, L.; Diederichs, S.; Kleinhenz, M.; Krechel, M. Greenhouse Gas Balances for Timber Buildings-Implementation of New Requirements for Life-Cycle Assessments and Calculation of Empiric Substitution Factors; Ruhr University Bochum: Bochum, Germany, 2017; ISBN 978-3-00-055101-7.

(C) 2020 by the authors. Licensee MDPI, Basel, Switzerland. This article is an open access article distributed under the terms and conditions of the Creative Commons Attribution (CC BY) license (http://creativecommons.org/licenses/by/4.0/). 